\title{
Enhancing EFL Learning in Cameroon's Language Centres through Content and Language Integrated Learning
}

\author{
Pius W. Akumbu \\ University of Buea, Cameroon \\ e-mail:akumbu.pius@ubuea.cm \\ Charlotte D. Simo \\ University of Buea, Cameroon \\ e-mail:dguidgec@yahoo.com
}

\begin{abstract}
This study seeks to determine how Content and Language Integrated Learning (CLIL), already applied successfully in other parts of the world, could be adapted to teaching English as a foreign language in language centres in Cameroon. The problem identified was the fact that 43 out of 64 students leave language centres with a lot of general English but with little or no language abilities relevant to their fields of experience, whether academic or professional. The results revealed that the implementation of CLIL had a positive impact on learners' development of diverse skills necessary for their success in academic and/or professional settings since there was a remarkable improvement in students' performance in the experimental group (93\%) as opposed to the limited (lower) performance of the control group (56.4\%), providing therefore factual evidence of the effectiveness of the CLIL approach over other conventional approaches in meeting students' needs and interests after training.

Keywords: CLIL, TEFL, language centre, conventional, performance
\end{abstract}




\section{INTRODUCTION}

An interest in Content and Language Integrated Learning (CLIL), in Europe and beyond, has increased exponentially since it first appeared on the scene in Europe in the early 1990's. CLIL has become a very much discussed topic in the literature on language education today with the number of publications pertaining to the field continuing to increase. The spread of scientific papers, methodological reflections, review articles, collections of research studies on the one hand, and of activities books, didactic materials, online blogs, etc. on the other, is an indication of this interest, as seen in the following recent studies.

Sylvén (2013) investigates how CLIL teaching is executed in Norway and how students develop within this teaching approach. In so doing, she proposes a study that focuses on several aspects of CLIL that have hitherto not been researched in Norway: progression of active language skills (writing), observation of CLIL classrooms, teacher perspectives and student attitudes, while bearing in mind, however, that CLIL teaching varies depending on the teacher, class and country. She compares empirical results from CLIL research done in Finland, Germany, Spain, and Sweden and argues that CLIL is not an effective teaching approach in Sweden. The article concludes that the success in the other countries can be due to factors such as clear national CLIL policies, bilingual teacher training, low age of implementation and amount of extramural English. Sylvén suggests that the Nordic countries will not see positive results for CLIL because there exist no national policies nor teacher training to support the CLIL approach, and its implementation is too late (upper secondary school). Furthermore, she believes that since the Nordic countries have such a high exposure to English, CLIL teaching will not make much of a difference.

Clotilde \& Andrea (2016) combined CLIL (Content and Language Integrated Learning) with Inquiry Based Science Education (IBSE) methodology. Through the "chemistry, CLIL and IBSE" project work, they chose to create a lesson on spectroscopy, to combine CLIL and ISBE methodologies using ITC tools in order to engage and motivate students in both science experiences and foreign language communication.

Kampen, Admiraal \& Berry (2018) present the outcomes of a study about the self-reported pedagogical practices of CLIL teachers in the Netherlands through a questionnaire completed by 297 teachers (218 CLIL teachers and 79 regular teachers) from secondary schools across the country. The results of the CLIL teachers were compared to a sample of regular teachers. Three main findings emerged from the study: First, CLIL teachers report using more pedagogical approaches focusing on providing students with diverse input and scaffolding than approaches focusing on developing students' language and their knowledge of disciplinary literacies. Second, the subject discipline of a CLIL teacher seems to influence the pedagogical approaches they report using. Third, there is a notable difference between the kinds of pedagogies reported by CLIL teachers and their regular counterparts.

Merino \& Lasagabaster (2018) examine the effect of CLIL sessions and their intensity on the learning of English as a foreign language through two test rounds 
conducted in a longitudinal study spanning one year. They used 393 secondary education students enrolled in both bilingual and monolingual regions in Spain and their findings revealed a significant impact of the number of CLIL sessions on students' proficiency in English.

In their preface, Richards and Rodgers (2001) tracing the history of language teaching emphasised the urgent need to formulate instructional techniques that build up effective language skills that guarantee both academic and career success in this ever changing world:

The history of language teaching has been characterised by a search for more effective ways of teaching second or foreign languages. For more than a hundred years, debates and discussions within the teaching profession have often centred on issues such as the role of grammar in the language curriculum, the development of accuracy and fluency in teaching, the choice of syllables framework in course design...teaching productive and receptive skills, learning theories and their application in teaching, memorisation and learning, motivating learners, effective learning strategies, techniques for teaching the four skills and the role of materials and technology. (p.viii)

The authors argue that although much has been done in handling the above preoccupations, the teaching profession is continually in search of new options for addressing these and the effectiveness of different instructional strategies and methods in the language classroom. This view is supported by Abebe's (2013, p.134) assertion on the importance of mastery of academic language skills as "one of the most reliable ways of achieving academic success and career development in today's world." As part of these efforts, this study investigates the role of CLIL in achieving the goal of building up effective language skills for both academic and professional success after training in language centres in Cameroon.

Coyle, Hood \& Marsh (2010) consider CLIL to be “... a dual-focused educational approach in which an additional language is used for the learning and teaching of both content and language. CLIL involves the use of languagesupportive methodologies leading to authentic learning where attention is given to both the topic and the language of instruction" As stated in the Eurydice report (2006, p. 8), "Achieving this twofold aim calls for the development of a special approach to teaching, in that the non-language subject is not taught in a foreign language but with and through a foreign language". This study therefore, focuses on exploring CLIL as an approach that could be used in the public and private language centres in the North-West and South-West regions of Cameroon to meet the needs of each learner for academic and/or professional success.

The future professional world of students is a life-long learning process in which they have to adapt to a changing market and an environment full of new opportunities and challenges. The development of a number of personal and professional skills, in addition to technical content and knowledge, is supposed to be a crucial part of their learning process. Among these skills, the knowledge of modern languages, especially English - the lingua franca of science and technology today - stands as pivotal to achieving successful communication, which is a 
fundamental ability in an increasingly globalised world. A good number of people are already aware of this challenge and resort to language institutions for help. In Cameroon most specifically, people come from Chad, Gabon, Equatorial Guinea, and even beyond, as well as from the French-speaking parts of Cameroon to the two English-speaking regions in search of English.

As far as we know, no study has focused on the application of CLIL as a language teaching approach in Cameroon. In other parts of the world, studies on have focused mainly on specific vocational trades. The innovation of our study is that it proposes that CLIL should be applied in language centres where learners with different trades or professions and needs converge. This is one of the elements that make this study unique since a majority of studies so far mainly focused on content pertaining to a well determined domain.

The focus is the language used to teach the different contents to the learners. In this case, we are in an English language classroom, in a language centre, teaching English as a foreign language to people with different needs and interests in the same class, while exploring the professional and/or academic expectations of each of the learners. Thus, the basic idea behind the integration of content and language is that "the English language is not learned first and then used but that it is learned by being used" (Genesee \& Lindholm-Leary, 2013). The intention therefore is not to separate or group students according to their needs and teach them in different groups like it is done in the teaching of English for specific purposes (ESP); rather they are all in the same group and their needs handled accordingly. Doing this automatically reduces the load of hours taught by each teacher giving them enough time for the preparation of their lessons for more effectiveness.

\section{BACKGROUND INFORMATION}

Prior to the research a baseline study was undertaken with graduates from language centres who were continuing their studies in higher institutions in Buea and Bamenda to determine the impact of the English language learnt from language centres on their performance in those schools. The study found that two thirds (43) of the 64 students observed that they still faced enormous difficulties in understanding the subject matter in their different fields of study. The general complaint was that they could hardly link the English learnt to what they were studying. They felt frustrated and disappointed that they were still having difficulties communicating effectively after graduating from a nine- or twelve- month English language course.

This situation, coupled with the researcher's experience of many years of teaching English and French to young and adult learners from the neighbouring countries to Cameroon cited earlier as well as to some Cameroonians of French expression, prompted the present study. There is clearly a need to reflect on the teaching methods used so far in the public and private language centres in Cameroon as well as the kind of curricula that exist. It is argued in this work that this problem could be solved if the CLIL approach of teaching was adopted and used and a contextualized CLIL curriculum designed accordingly. The study advocates that only an integrated interdisciplinary approach between language and academic or 
professional subject studies can produce the synergy needed to prepare highlyqualified specialists in a particular field of study or work. This is why there is an urgent need to shed light on CLIL as an approach which could be used in Cameroon language centres to foster the twofold goal of language tuition and learning that is, learning language not just for knowledge sake but for immediate use. In other words, using CLIL will mean teaching and learning language for effective communication thereby enabling learners to use the language they have learnt to be effective in their different domains of interest.

\section{LITERATURE REVIEW}

\subsection{On Subject Content Learning}

Dalton-Puffer (2007) points out that one of the main concerns of many researchers investigating the effectiveness of CLIL has been the issue of how the subject knowledge and skills of learners are affected when being taught in a foreign language. According to him despite the presence of the word integrated, the relationship between content and language in CLIL is characterized by a good deal of tension and sometimes conflict between the two areas:

This concern reflects two fears: firstly, that the foreign language may slow down proceedings, so that less subject matter can be covered and secondly, that lower language proficiency may result in reduced cognitive complexity of the subject matter presented and/or learned. The concern is thus about both coverage and depth. (Dalton-Puffer, 2007, p.5).

It is almost logical to think that since the knowledge of the language used for communication has not yet been mastered, this might negatively affect the understanding and competence in the subject content knowledge and skills needed by students. In Hajer's view,

Most interaction studies focus on language form and functions and on the structures of participation. However, in content area teaching the thematic content is not only a trigger for pupil participation, but a goal on its own. . . . the challenge of education is to lead students into theoretical knowledge and academic language, building on their daily communicative skills and daily knowledge (2000, p.229).

Teachers might unintentionally contribute to this problem of potentially reduced subject competence when, in their attempt to facilitate learning, they oversimplify the contents beforehand. According to Van Lier (1988), the design of learning tasks used in the classroom to present both linguistic and thematic contents is essential and should consider complexity and resources to achieve an adequate interrelatedness of social and academic aspects. Van Lier (1988) argues that thematic content complexity should be included as another influencing factor to focus on in classroom research.

Amado (2012) argues that the results of research on regarding subject content learning have been generally positive. Most studies show that CLIL learners possess 
the same amount of subject knowledge as those students taught in their first language. Moreover, the study showed that CLIL students perform even better than their L1 peers when tested in their mother tongue.

\subsection{On Language Learning}

Amado (2012, p.18) further points out that the vast majority of studies concerning the effects of CLIL on the language learning outcomes have been favourable to this approach. CLIL has been generally found to affect language learning outcomes in an unsurprisingly positive way. It is often observed that by way of CLIL students can reach significantly higher levels of L2 than by conventional foreign language classes and positive effects on communicative competence are also visible.

She goes further to argue that international standards have been used to compare a group of CLIL students and their non-CLIL peers in a placement test. The results showed that a higher percentage of students from the CLIL group reached the required B2 level (according to the Common European Framework of Reference for languages (CEFR)) when compared to the group who had followed only a conventional EFL curriculum. In the study, although some of the non-CLIL students presented top scores, a larger number of students from the CLIL group were just below the top level. These results seem to suggest that whereas learners with remarkable linguistic aptitudes seem to be able to reach high proficiency, even following the regular $E F L$ classes, the language skills of a broader group of average learners can be significantly enhanced through CLIL.

Amado's (2012) study which focused on the effectiveness of a Content \& Language Integrated Learning course and the interwoven development of content, communication, cognition and culture - through Task Based Learning - in the enhancement of students' interlanguage, tested according to the components of Communicative Language Ability yielded the results presented below.

The results obtained in the diagnostic test show that there was an acceptable performance of the control group in the communicative tasks, written and spoken. There was also a regular performance in the tasks connected to receptive skills, reading and listening, which were assessed more objectively. The value obtained for the mean in this test (27.81 points) represented $69.50 \%$ of the 40 points for which the test was designed. This looked rather promising considering that this was the first time students had been exposed to a test of the kind including not so familiar content.

However, the results in the achievement test didn't indicate any improvement since they were significantly lower. Although there were a few students that reached and surpassed their previous score, the general performance of the group decreased to $66.25 \%$. Students' performance in the communicative tasks was barely similar to that in the diagnostic test, and even poorer in what concerns textual and illocutionary competences. Moreover, their strategies to communicate effectively were not developed according to what was expected to complete the tasks in the test successfully. This is not surprising if one considers that students in this group lacked 
the experience in tasks with which the experimental group benefited due to the course they took.

The author then concluded that the limited performance of the control group in the achievement test could well be attributed to content (lack of familiarity with the contents of the test, although the topic was carefully selected so as to make it equally familiar to both groups that took part in this research); communication (lack of training in strategies to approach the tasks presented and to use their language skills for a more effective communication) and cognition (lack of training in the use of cognitive skills to interpret, analyze, synthesize and evaluate concepts while using the language as a tool to perform these actions).

On the other hand, the general performance of the experimental group in the diagnostic test was less acceptable than the performance of their peers in the control group. The communicative tasks, especially their writing, showed an evenly lower development for all the competences. Their performance in tasks connected to receptive skills was almost similar to that found in the control group, but their limited capacity to communicate effectively determined their final scores in the test. The 25.25 points obtained for the mean were $63.13 \%$ of the 40 points that were possible to obtain in the test. These results were considerably lower than those in the control group. This was a real challenge that needed to be faced by the course in order to help these students experience an observable improvement in their language.

The results in the final achievement test were remarkably higher than the results in the diagnostic test for the same group, and higher than any of the results in the control group. All the students who were part of the experimental group surpassed their previous total score and that gave the group a more than acceptable mean of 32.17 points representing a striking $80.43 \%$ performance. The group members improved significantly in their ability to communicate more effectively in written and spoken tasks. Also, they were more aware of and familiar with the use of cognitive skills to approach different activities.

Following the above, Amado concluded that the outstanding performance in the achievement test and remarkable improvement of the experimental group could well be assumed to be due to content (enhanced familiarity with vocabulary and general concepts connected to art, style and appreciation, although the topic was generally discussed in the control group, too). Communication (awareness of strategies to organize thoughts, present opinions, support ideas and, in general, use the language to communicate more effectively) and cognition (embedded use of cognitive skills to complete tasks that demand to interpret, analyze, synthesize and evaluate concepts, while requiring the language as a tool).

Amado suggested that it could be possible to adapt the principles of Content \& Language Integrated Learning which respond to the demands of enhancing cognitive and communicative skills through the development of lessons according to students' interests and needs. At the end of the study, the author goes further to posit that CLIL constitutes an alternative approach that intends to give attention to the different dimensions of language learning, the "how" and the "what" we learn, and to give equal relevance to content, cognition, communication and culture, within the 
context of a subject that permits enhancing students' motivation and catering for their increasing specialized needs.

\section{RESEARCH METHODS}

\subsection{Participants}

There were 273 participants in this study sub-divided as follows: 64 participants (former students of language centres studying in professional schools) for the baseline study, 159 participants (137 current students and 22 authorities from ten language centres in Buea and Bamenda for the survey phase of the study and 50 participants (current students at ILANI) for the quasi-experimental phase of the study.

\subsection{Procedures}

\subsubsection{The Baseline Study Phase}

During the baseline study phase of the research 86 questionnaires were administered to former students of language centres studying then in professional schools to determine the impact of English language learnt on their studies; 64 were recovered by the researcher giving a percentage return rate of $74.41 \%$. The actual research comprised two sub-parts, namely the survey and the quasi-experiment.

\subsubsection{The Survey Phase}

During the survey phase of the study, of the 164 questionnaires administered to students of language centres, 137 were recovered by the researcher giving a percentage return rate of $83.53 \%$. An $81.48 \%(66.66 \%$ in Buea and $100 \%$ in Bamenda) return rate was recorded in the recovery of 22 questionnaires out of the 27 administered to the selected language centre authorities in Buea and Bamenda. The data collected from the observational checklist were equally analysed.

\subsubsection{The Experimental Phase}

The quasi-experiment was carried out, during a period of 12 weeks (three months), on 50 students of the Institute of Languages for International Integration (ILANI), based in Buea, (following a CLIL project inspired by Coyle (2005) with the aims to build essential qualities for academic and professional success in learners; discover the essential knowledge and skill base required for academic and professional success and apply same to real life situations) to verify the impact of CLIL on their performance in English language. After using conventional methods and CLIL to teach the control and the experimental groups (25 students in each group) respectively, the performances of the two groups were compared. Finally, a follow up survey was carried out on 32 students, graduates of ILANI and participants of the experiment, to determine the impact of CLIL on their performances in some higher institutions of learning in Buea and to gather information about their performance in such settings after a period of three months (from October to December 2015) in January 2016. The quasi-experimental design comprised the following major steps: 
First, Assigning control and experimental groups: 50 students of the Institute of Languages for International Integration (ILANI) for an English language course of over nine months were selected and trained for five months up to intermediate level. After this period they were evaluated and later assigned to both the control and experimental groups, using a stratified random sampling technique. This technique ensured that both groups (of 25 students each) had similar characteristics such as gender, first language, nationality, level of education, and age following their test performance and a class list that had such information. The control group was labelled "Group A" and the experimental group "Group B".

Second, Pre-testing: Within the first month of the experiment, both groups studied English language under two tutors (guided by the researcher) who taught alternatively using the same conventional methods and content, from $8 \mathrm{am}$ to $10 \mathrm{am}$ and from 10 am to 12 noon, from Monday to Friday. The above situation was to ensure that both groups were exposed to the same conditions (time of the day, methods and contents, teachers, learning environment, mixed grouping in terms of age, gender, language background, etc.). At the close of the first month of teaching, a test was given to both groups on the same day and at the same time (8 am to 10 am) and the scores were recorded, to determine the degree to which the control and the experimental groups vary in terms of performance at the test. The logic of this step was that if the pre-treatment measures or scores (before introducing CLIL) were identical or nearly so, despite non-equivalence between the experimental (Group B) and control (Group A) groups, we would feel more comfortable using the control group as a control.

Third, the treatment step: this is when CLIL was introduced exclusively to Group B as a language teaching-learning approach for a period of three months in the course of the training of both groups, ensuring that all conditions that existed prior to this step were found in both groups throughout the experiment. This was to avoid other factors besides teaching methods influencing performance in both groups. During this third step the CLIL approach was applied to the experimental group.

Forth, after intervention step: the graduates from ILANI were contacted in their different schools through phone calls, the Internet and with the assistance of other graduates as well as residents in the towns under study. Some language centre authorities equally facilitated the possibility of the researcher meeting the respondents under study. Out of the 50 participants of the experiment at ILANI 32 could be traced in some professional institutions in Buea to whom a post questionnaire was administered.

\subsection{Instruments}

Data analysis was based on 137 usable questionnaires for students in language centres and 22 questionnaires for language centre authorities in the two towns under study in 2015. An observational checklist also offered qualitative data for the study thereby overcoming the limitations of the questionnaire. This was followed by a quasi-experiment on students of ILANI from July - September 2015 to determine the 
impact of CLIL on their performance in English language and predict the same, both in academic and professional settings in the future.

In order to verify the impact of CLIL on the performance of graduates after school, a questionnaire (post-testing) was addressed to the graduates of ILANI (control and experimental groups) in their various schools to gather information about their performance in such settings after a period of three months (from October to December 2015), in January 2016. However, the data collecting procedure often meant several trips, once every week, for a period of six months, to recover questionnaires and observe actual teaching and learning in the language centres. As seen, the research comprised three main phases: The baseline study phase, the actual research (survey and experiment) and the after intervention phase as highlighted in the table below.

Table 1: Summary of research design, phases of the study and instruments used

\begin{tabular}{|c|c|c|c|}
\hline Research Phases & Research Type & Purpose & Instruments \\
\hline $\begin{array}{l}\text { Before Research } \\
\text { : Baseline study } \\
\text { (Oct.-Dec. } \\
\text { 2014) }\end{array}$ & Survey & $\begin{array}{l}\text { To determine the impact of } \\
\text { English language learnt on } \\
\text { students' performance in } \\
\text { selected } \\
\text { vocational/professional } \\
\text { schools }\end{array}$ & $\begin{array}{l}\text { Questionnaires (former } \\
\text { students of language centres in } \\
\text { selected vocational/professional } \\
\text { schools) }\end{array}$ \\
\hline \multirow{3}{*}{ During research } & $\begin{array}{l}\text { 1-Survey (Jan. } \\
2015 \text { - June } \\
2015)\end{array}$ & $\begin{array}{l}\text { To determine the on-going } \\
\text { English language } \\
\text { teaching/learning process in } \\
\text { various language centres }\end{array}$ & $\begin{array}{l}\text { Questionnaires (current } \\
\text { students in language centres) } \\
\text { Questionnaires (teachers \& } \\
\text { administrators) } \\
\text { Observational checklist } \\
\text { (classroom interactions) }\end{array}$ \\
\hline & $\begin{array}{l}\text { 2-Selection and } \\
\text { training of } \\
\text { participants for } \\
\text { the acquisition } \\
\text { of basic and } \\
\text { Intermediate } \\
\text { level English } \\
\text { (Jan. - May } \\
\text { 2015) at ILANI }\end{array}$ & $\begin{array}{l}\text { Training and evaluation to } \\
\text { make sure that the } \\
\text { participants have acquired a } \\
\text { level of basic and } \\
\text { intermediate English }\end{array}$ & Classroom teaching/ learning \\
\hline & $\begin{array}{l}\text { 3-Quasi- } \\
\text { experiment } \\
\text { (June 2015- } \\
\text { Sept. 2015) }\end{array}$ & $\begin{array}{l}\text { To determine the impact of } \\
\text { CLIL on students' } \\
\text { performance in English } \\
\text { language at ILANI and } \\
\text { subsequently in academic } \\
\text { and/or professional settings }\end{array}$ & $\begin{array}{l}\text { Tests (Teaching experimental } \\
\text { group with CLIL and the } \\
\text { control group without CLIL, } \\
\text { and evaluating the language } \\
\text { level of both control and } \\
\text { experimental groups at ILANI) }\end{array}$ \\
\hline $\begin{array}{l}\text { After } \\
\text { intervention } \\
\text { /training: } \\
\text { operational } \\
\text { evaluation (Jan. } \\
\text { 2016) }\end{array}$ & 4-Survey & $\begin{array}{l}\text { To determine the extent to } \\
\text { which CLIL has impacted } \\
\text { graduates' performance } \\
\text { (control and experimental } \\
\text { groups) in their } \\
\text { professional/vocational } \\
\text { schools }\end{array}$ & $\begin{array}{l}\text { Questionnaires (administered } \\
\text { to graduates of ILANI in } \\
\text { various professional/ vocational } \\
\text { schools) }\end{array}$ \\
\hline
\end{tabular}




\section{RESULTS AND DISCUSSIONS}

The results of the different phases of the research design (baseline study, survey, experiment and follow-up survey) revealed that the teachers and administrators of language centres in Cameroon, particularly in Buea and Bamenda do not know about CLIL and therefore cannot implement it in their centres. This is evident in the responses of both students and administrators during the survey. While most of the students (81 (59.2\%) against 56 (40.8\%) were generally dissatisfied with the teaching methods used in their development of critical thinking, creativity and execution of concrete communication tasks, the teachers and administrators agreed (63.6\% strongly agreed and $36.4 \%$ agreed) on the need to effectively link the English learnt and taught to the learners' future endeavours. This was also confirmed by both the 42 out of 64 students in the baseline study who reported that the English language they had learnt did not help them much in their studies, and the results from the observational checklist which revealed that the teaching methods and materials used did not reflect real world situations that could arouse learners' interests and address their needs.

Also, the diagnostic test administered before the experiment was conducted, and the achievement test, given once the course was completed, prompted data collection from both the experimental and the control groups which were analysed according to central tendency and dispersion indicators. The findings showed that all the students who were part of the experimental group surpassed their previous total score and that gave the group a more than acceptable mean (average) of $13.44 \pm 0.49$ which was a striking performance. This was mainly because the experimental group had improved significantly their strategies to communicate more effectively in written and spoken tasks. Equally, they were more aware of and familiar with the cognitive skills in tackling different activities. The remarkable improvement in students' performance in the experimental group as opposed to the limited (lower) performance of the control group, providing factual evidence of the effectiveness of the CLIL approach over other conventional approaches in meeting students' needs and interests after training.

These results reflect what Amado (2012) found, namely, that the final achievement test of the experimental group were remarkably higher than the results in the diagnostic test for the same group, and higher than any of the results in the control group. Even though the experimental group consisted of only six students, the author argues that the fact remains that all the students in this group responded positively to "being propelled forward" by the activities planned for the development of the content based course.

Moreover, the results of the follow-up survey revealed that the learners of the experimental group (93\%) were more satisfied with the ability of the contents and teaching methods they had been exposed to (that is CLIL) to impart knowledge and skills required to be used in their respective current endeavours as compared to only $56.4 \%$ of the control group who had been exposed to the same content, but with the use of conventional methods.

Similar results have also been reported by studies on CLIL in Asia. Yamano (2013) noted that "utilizing the CLIL approach in a Japanese primary school has the 
potential to improve Japanese primary EFL education”. Burrows (2013), on his part in a study in Thailand, reported that the analysis of pre-/post-testing of English language competencies and a survey of participant opinions suggest that "the CLIL approach was beneficial for the participants", and that the program was found to be consistent with such established CLIL principles.

The results of the follow-up survey of students who participated in the experiment, further provide evidence that the CLIL approach and the design of a CLIL course enhance the development of communicative and linguistic skills needed by learners to carry out real world tasks in academic and professional settings more than other conventional approaches.

\section{CONCLUSION}

This study investigates the role of CLIL in achieving the goal of building up effective language skills in learners for both academic and professional success after training in language centres in Cameroon. It springs from a baseline study which revealed that former students of language centres studying then in professional schools could not use the English language learnt with efficiency in their studies. In order to find out the cause of this gap between the English language learnt and the proficiency of the learners, an observation, a survey and an experiment were conducted on learners in some language centres in Buea and Bamenda. The study revealed that language centres' administrators and teachers are unaware of the CLIL approach. It was also noted that conventional language teaching methods are not effective enough to enable the trained students from language centres to use the English language learnt in their different endeavours. The post-survey revealed that the students of the experimental group who were taught using the CLIL approach had an advantage over those of the control group, thus giving room to proposing CLIL as an approach that could be used in language centres for better results and efficiency in the different fields of application by the learners.

Though adopting effective implementation of CLIL in language centres still needs to take some time, it goes without saying that CLIL will likely be the most appropriate approach to be used in language centres in the teaching/learning process of EFL in (language centres) Cameroon. Nonetheless, getting rid of the other conventional methods because there is lack of satisfaction on the part of the learners does not appear to be a sensible solution since there are not yet qualified teachers to implement CLIL. However, it is necessary for language teachers to be aware of the fact that conventional methods do not work for students' in language centres, and to seek to know about CLIL and how to implement it effectively.

It is hoped that the findings of this study could motivate more research in the field of CLIL for many different specialised content areas, be them academic or professional, and equally awaken the curiosity of policy makers, language teachers and administrators of language centres to learn more about CLIL and its implementation. 


\section{REFERENCES}

Abebe, W. Y. (2013). Fostering academic genre knowledge of EFL learners through Content and Language Integrated Learning (CLIL). International Journal of Society, Culture and Language (IJSCL), Vol. 1, 133-144. Retrieved from www.ijscl.net

Amado, A. (2012). The design of content \& language integrated learning (CLIL) course for the interwoven development of content, communication, cognition \& culture.(Maestría en Educación con Mención en Enseñanzade ingles comoLenguaExtranjera. Universidad de Piura. Facultad de Ciencias de la Educación). Piura, Perú.

Burrows, T. (2013). English and integrated water resource management: A training program for the Mekong River Commission. In P. Robertson \& J. Adamson (Eds.), The Asian EFL Journal. CLIL in Asian Contexts: Emerging Trends. 15(4), 37-64. Asian EFL Journal Press:Thailand.

Clotilde, B. M. \& Andrea, C. (2016). CLIL \& IBSE methodologies in a chemistry learning unit. European Journal of Research and Reflection in Educational Sciences. 4(8), P.1. Progressive Academic Publishing, UK. Retrieved from www.idpublications.org

Coyle, D. (2005). CLIL: Planning tools for teachers. Nottingham: University of Nottingham.

Coyle D., Hood P. \& Marsh D. (2010). CLIL: Content and language integrated learning. Cambridge: Cambridge University Press.

Dalton-Puffer, C. (2007). Discourse in content and language integrated learning (CLIL) classrooms. Amsterdam: John Benjamins.

Eurydice report. (2006). Content and language integrated learning (CLIL) at school in Europe. Brussels: Eurydice. Retrieved from http://ec.europa.eu/languages/documents/studies/clil-atschoolineurope_en.pdf.p.8.

Genesee, F., \& Lindholm-Leary, K. (2013). Two case studies of content-based language education. Journal of Immersion and Content-based Language Education, 1, 3-33. Retrieved from doi:10.1075/jicb.1.1.02gen.

Hajer, M. (2000). Creating a language-promoting classroom: Content-area teachers at work. In Hall, J. K. \& Verplaetse, L. S. (Eds.). (2000). Second and foreign language learning through classroom interaction (pp. 265-285). London: Lawrence Erlbaum Associates.

Hellekjær, G. O., \& Hopfenbeck, T. (2012). Lesing. Fokus på språk, 28, 84-124.

Kampen , E. V., Admiraal, W. \& Berry, A. (2018). Content and language integrated learning in the Netherlands: teachers' self-reported pedagogical practices. International Journal of Bilingual Education and Bilingualism. Retrieved from DOI: 10.1080/13670050.2016.1154004

Merino J. A. \& Lasagabaster, D. (2018). The effect of content and language integrated learning programmes' intensity on English proficiency: A longitudinal study. International Journal of Applied Linguistics. 28(1), 18-30. Retrieved from https://doi.org/10.1111/ijal.12177 
Richards, J. C., \& Rodgers, T. S. (2001). Approaches and methods in language teaching. Cambridge: Cambridge University Press.

Sylvén, L. K. (2013). CLIL in Sweden: why does it not work? A metaperspective on CLIL across contexts in Europe. International Journal of Bilingual Education and Bilingualism, 16(3), 301-320.

Van Lier, L. (1988). The classroom and the language learner. Ethnography and second-language classroom research. Harlow: Longman.

Yamano, Y. (2013). Utilizing the CLIL approach in a Japanese primary school: A comparative study of CLIL and EFL lessons. The Asian EFL Journal Special Edition: CLIL in Asian Contexts: Emerging Trends. Paul Robertson and James Adamson (Eds.). Asian EFL Journal Press, 15(4). 